\title{
1 An effect of the COVID-19 pandemic: significantly more complicated 2 appendicitis due to delayed presentation of patients!
}

3

4 Marie Burgard ${ }^{1 \uparrow}$, Floryn Cherbanyk ${ }^{1 \uparrow}$, Konstantinos Nassiopoulos ${ }^{2}$, Sonaz Malekzadeh ${ }^{3}$, François

5 Pugin $^{1}$, Bernhard Egger ${ }^{1}$

6

7

8

$9{ }^{1}$ Department of Surgery, HFR Fribourg - Cantonal Hospital Fribourg, Switzerland

$10{ }^{2}$ Department of Surgery, Daler Hospital Fribourg, Switzerland

$11{ }^{3}$ Department of Diagnostic and Interventional Radiology, HFR Fribourg - Cantonal Hospital Fribourg,

12 Switzerland.

* Corresponding author 


\section{Abstract}

22 AIMS OF THE STUDY: The novel coronavirus pandemic has affected emergency department consultations for surgical pathologies. The aim of our study was to compare the number of acute appendicitis cases and the proportion of complicated appendicitis before and during the COVID-19 pandemic.

METHODS: We retrospectively analyzed all data collected from a multi-center database of patients presenting to the emergency department for acute appendicitis during the COVID-19 pandemic from March 12 to June 6, 2020, and compared these data with those from the same periods in 2017, 2018, and 2019. The number of acute appendicitis cases, proportion of complicated appendicitis, and pre- and postoperative patient characteristics were evaluated.

RESULTS: A total of 306 patients were included in this evaluation. Sixty-five patients presented during the 2020 COVID-19 pandemic lockdown (group A), and 241 patients in previous years (group B: 2017-2019). The number of consultations for acute appendicitis decreased by almost 20 percent during the pandemic compared with previous periods, with a significant increase in complicated appendicitis (52\% in group A versus $20 \%$ in group $B, p<0,001$ ). Comparing the two groups, significant differences were also noted in the duration of symptoms (symptoms $>48 \mathrm{~h}$ in $61 \%$ and $26 \%, p<0,001$ ), the intervention time ( 77 vs 61 minutes, $p=0,002$ ), length of hospital stay ( hospitalization of $>2$ days in $63 \%$ and $32 \%, p<0.001)$ and duration of antibiotic treatment ( antibiotics $>3$ days in $36 \%$ and $24 \% p=0.001$ ).

40 CONCLUSIONS: The COVID-19 pandemic resulted in a decreased number of consultations for 
medRxiv preprint doi: https://doi.org/10.1101/2021.01.23.21250358; this version posted January 25 , 2021. The copyright holder for this preprint

(which was not certified by peer review) is the author/funder, who has granted medRxiv a license to display the preprint in perpetuity.

All rights reserved. No reuse allowed without permission.

42 delay in consulting the emergency department at symptom onset. Patients and general practitioners

43 should be aware of this problem to avoid a time delay from initial symptoms to consultation.

\section{Introduction}

46 The novel coronavirus SARS-CoV-2 (causing COVID-19) was first recognized in China in December

472019 and rapidly spread throughout the world. The COVID-19 disease outbreak was declared a pandemic by the World Health Organization (WHO) on March 11, 2020 [1]. Because of the high contagious potential of this virus, many hospitals quickly experienced patient overload and an increased need to use respiratory assistance in infected patients. Consequently, many countries announced a state of emergency and advised the population to stay at home whenever possible. However, patients' fear of becoming infected by the virus obviously also led to a marked reduction in consultations at emergency departments, even in the case of abdominal symptoms [2].

Appendicitis is one of the most common causes of acute abdominal pain and is one of the most frequent reasons for emergency surgery [3]. Complicated appendicitis is defined as gangrenous or perforated appendicitis or peri-appendicular abscess formation. Longer duration of symptoms prior to consultation is a well-known risk factor for developing complicated appendicitis [4].

During the COVID-19 pandemic, the number of consultations for acute appendicitis decreased. While some studies demonstrated a higher rate of complicated appendicitis, probably due to delayed consultation, other studies have reported no change in the rates of uncomplicated/complicated appendicitis during this period [5-8].

The aim of our study was to analyze the incidence of acute appendicitis as well the rates of uncomplicated/complicated appendicitis during the COVID-19 lockdown period and to compare these data with a comparable period in previous years. We found that the COVID-19 pandemic 
medRxiv preprint doi: https://doi.org/10.1101/2021.01.23.21250358; this version posted January 25 , 2021. The copyright holder for this preprint

(which was not certified by peer review) is the author/funder, who has granted medRxiv a license to display the preprint in perpetuity.

All rights reserved. No reuse allowed without permission.

66 consultation, a higher proportion of complicated appendicitis, longer use of post-surgery antibiotic

67 treatment, and longer hospital stay, most likely due to patient delay in consulting the emergency department at symptom onset.

\section{Materials and methods}

Data from patients was extracted from prospective digital databases of a multi-site tertiary care hospital (HFR, Cantonal Hospital of Fribourg) and a secondary care hospital (Daler Hospital). The retrospective analysis included all patients who presented at the respective EDs for acute appendicitis during the COVID-19 lockdown period in Switzerland from March 12 to June 6, 2020 (group A), and for comparison data of patients presenting for the same reason and during the same period of the year in 2017, 2018, and 2019 (group B).

\section{Data analysis}

Demographic data, biologic and inflammatory markers at presentation, duration of symptoms until presentation to the ED, duration of antibiotic treatment, and duration of hospital stay were recorded. Each operation protocol was separately evaluated and the severity of appendicitis classified according to the laparoscopic grading score of Gomes [9]: briefly, normal-looking appendix $=$ grade 0 , non-complicated appendicitis with redness and edema = grade 1 , with additional fibrin layers $=$ grade 2 , complicated appendicitis with segmental peripheral necrosis $=$ grade $3 \mathrm{~A}$, with necrosis of the appendix base $=$ grade $3 \mathrm{~B}$, with abscess formation $=$ grade $4 \mathrm{~A}$, with regional peritonitis $=$ grade $4 \mathrm{~B}$, and with diffuse peritonitis $=$ grade 5 .

In addition, histopathologic results were recorded and classified into five groups: grade $0=$ no inflammation, grade 1 = acute appendicitis, grade $2=$ ulcero-phlegmonous appendicitis, grade $3=$ necrotizing or gangrenous appendicitis, grade $4=$ abscess formation, and grade $5=$ perforated appendicitis. Grades 1 and 2 were classified as non-complicated and grades $3-5$ as complicated appendicitis. 
medRxiv preprint doi: https://doi.org/10.1101/2021.01.23.21250358; this version posted January 25, 2021. The copyright holder for this preprint

(which was not certified by peer review) is the author/funder, who has granted medRxiv a license to display the preprint in perpetuity.

All rights reserved. No reuse allowed without permission.

90 Finally, patient data were compared between group A (COVID lockdown, March 12-June 6, 2020)

91 and group B (March 12-June 6, 2017, 2018, and 2019).

\section{Statistical analysis}

93 Statistical analysis was performed utilizing the Statistical Package for Social Sciences, version 27.0

94 (SPSS, IBM, Armonk, USA). Quantitative variables were expressed as mean \pm standard deviation (SD) and ranges. Qualitative variables were expressed as raw numbers, proportions, and percentages.

Pearson's chi-square test was used to search for differences between categorical variables while the Student t-test and Mann-Whitney $\mathrm{U}$ test were used for continuous variables. All results were expressed with a $95 \%$ confidence interval, and statistical significance was defined as a $P$ value $<0.05$.

This study was approved by the local Ethics Committee (Project -ID 2020-01676).

\section{Results}

\section{Number of appendicitis cases}

A total of 311 patients presented to the respective EDs for suspicion of acute appendicitis during the reviewed periods. Five patients with a different peri-operative diagnosis were excluded from analysis. In all, 306 patients were enrolled, including 65 who presented during the COVID-19 lockdown and 245 in the years before (80 patients in 2017, 78 in 2018, and 87 in 2019). On an annual basis, the total number of patients presenting with acute appendicitis during the COVID-19 pandemic decreased by almost $20 \%$ when compared with the years before. 
medRxiv preprint doi: https://doi.org/10.1101/2021.01.23.21250358; this version posted January 25, 2021. The copyright holder for this preprint

(which was not certified by peer review) is the author/funder, who has granted medRxiv a license to display the preprint in perpetuity.

All rights reserved. No reuse allowed without permission.

\section{Patients' pre-operative characteristics}

112 There were no statistically significant differences in median age and sex distribution between the groups. In 12 patients, the duration of symptoms prior to consultation could not be re-evaluated. However, most of the patients in group $A(61 \%)$ presented at the ED more than $48 \mathrm{~h}$ after the beginning of symptoms, compared with $26 \%$ in group $\mathrm{B}(P<0.001)$. Regarding the biologic inflammatory markers at presentation, plasma C-reactive protein (CRP) was significantly higher in group A compared with group B $(P<0.007)$, while the white blood cell count (WBC) was only slightly and nonsignificantly higher in group $\mathrm{A}(P=0.438)$ when compared with group $\mathrm{B}$. The demographic, clinical, and biological data of the two groups are summarized in Table 1. 


\begin{tabular}{|c|c|c|c|c|}
\hline & $\begin{array}{l}\text { Total } \\
\text { (n=306) }\end{array}$ & $\begin{array}{l}\text { COVID-19 } \\
2020 \\
\text { Group A } \\
(n=65)\end{array}$ & $\begin{array}{l}\text { Non COVID-19 } \\
\text { 2017-2019 } \\
\text { Group B } \\
(n=241)\end{array}$ & $\begin{array}{l}134 \\
125\end{array}$ \\
\hline Age, median (range) & $28(6-86)$ & $29(6-86)$ & $30(6-82)$ & $\begin{array}{r}P=0.3636 \\
137\end{array}$ \\
\hline $\begin{array}{l}\text { Sex, n (\%) } \\
\text { Men } \\
\text { Women }\end{array}$ & $\begin{array}{l}174(57) \\
132(43)\end{array}$ & $\begin{array}{l}39(60) \\
26(40)\end{array}$ & $\begin{array}{l}135(56) \\
106(44)\end{array}$ & 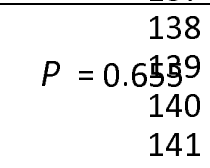 \\
\hline $\begin{array}{l}\text { Duration of } \\
\text { symptoms until } \\
\text { presentation to the } \\
\text { ED, } \mathrm{n} \mathrm{( \% )} \\
<24 \mathrm{~h} \\
24-48 \mathrm{~h} \\
48-72 \mathrm{~h} \\
>72 \mathrm{~h} \\
\text { unknown }\end{array}$ & $\begin{array}{c}92 \\
114 \\
53 \\
35 \\
12\end{array}$ & $\begin{array}{l}11(17) \\
14(22) \\
18(28) \\
14(21) \\
8(12)\end{array}$ & $\begin{array}{c}81(34) \\
100(40) \\
35(15) \\
21(9) \\
4(2)\end{array}$ & $\begin{array}{r}142 \\
143 \\
144 \\
145 \\
146 \\
147 \\
P<0.0918 \\
149 \\
150 \\
151 \\
152 \\
153 \\
154 \\
155\end{array}$ \\
\hline $\begin{array}{l}\text { Biologic inflammatory } \\
\text { markers, mean (SD) } \\
\text { WBC } \\
\text { CRP }\end{array}$ & $\begin{array}{l}13.1(0.3) \\
53.8(4.1)\end{array}$ & $\begin{array}{c}13.5(0,5) \\
75.8(10.6)\end{array}$ & $\begin{array}{c}13(0.3) \\
48.5(4.3)\end{array}$ & $\begin{array}{r}156 \\
157 \\
158 \\
P=0.438159 \\
P=0.007160 \\
161\end{array}$ \\
\hline
\end{tabular}

dard deviation; $\mathrm{WBC}=$ white blood cell count; $\mathrm{CRP}=\mathrm{C}$-reactive protein

\section{Operative and postoperative characteristics}

166 Six patients (2\%) were treated conservatively, one patient during the COVID-19 period and five

167 patients in group B. Among them, five patients presented with complicated appendicitis diagnosed on imaging and were treated using antibiotic therapy and transabdominal drainage. One patient with a non-complicated appendicitis and multiple comorbidities underwent antibiotic treatment only. laparoscopic intervention (Table 2). 
medRxiv preprint doi: https://doi.org/10.1101/2021.01.23.21250358; this version posted January 25, 2021. The copyright holder for this preprint (which was not certified by peer review) is the author/funder, who has granted medRxiv a license to display the preprint in perpetuity.

\begin{tabular}{|c|c|c|c|c|}
\hline & $\begin{array}{c}\text { Total } \\
\mathrm{n}=306(\%)\end{array}$ & $\begin{array}{c}\text { COVID-19 } \\
2020 \\
\text { Group A } \\
n=65(\%)\end{array}$ & $\begin{array}{c}\text { Non COVID-19 } \\
2017-2019 \\
\text { Group B } \\
n=241(\%)\end{array}$ & $P$ value \\
\hline $\begin{array}{l}\text { Treatment modalities } \\
\text { Operative treatment } \\
\text { Laparoscopic } \\
\text { Open } \\
\text { Conservative treatment } \\
\text { Antibiotics } \\
\text { Antibiotics and drainage }\end{array}$ & $\begin{array}{c}300(98) \\
299 \\
1 \\
6(2) \\
1 \\
5\end{array}$ & $\begin{array}{c}64(98) \\
64 \\
0 \\
1(2) \\
0 \\
1\end{array}$ & $\begin{array}{c}236(98) \\
235 \\
1 \\
5(2) \\
1 \\
4\end{array}$ & \\
\hline Time of intervention (minutes), mean (SD) & $64(2)$ & $77(6)$ & $61(2)$ & $P=0.002$ \\
\hline Conversion & $6(2)$ & $3(5)$ & $3(1)$ & $P=0.088$ \\
\hline Drainage & $47(16)$ & $18(28)$ & $29(12)$ & $P=0.002$ \\
\hline $\begin{array}{l}\text { Laparoscopic classification (Gomes score) } \\
0 \text { - Normal-looking appendix } \\
\text { Non-complicated appendicitis } \\
1 \text { and } 2 \text { - Hyperemia, edema, and } \\
\text { fibrinous exudate } \\
\text { Complicated appendicitis } \\
3 a-\text { Segmental necrosis } \\
3 b-\text { Basal necrosis } \\
4 a-\text { Abscess } \\
4 b-\text { Regional peritonitis } \\
5 \text { - Diffuse peritonitis }\end{array}$ & $\begin{array}{c}14(5) \\
204(68) \\
\\
20(7) \\
3(1) \\
10(3) \\
37(12) \\
12(4)\end{array}$ & $\begin{array}{c}1(2) \\
30(46) \\
\\
\\
9(14) \\
0 \\
1(2) \\
16(25) \\
7(11)\end{array}$ & $\begin{array}{c}13(6) \\
174(74) \\
\\
11(15) \\
3(1) \\
9(4) \\
21(9) \\
5(2)\end{array}$ & $P<0.001$ \\
\hline $\begin{array}{l}\text { Histological classification } \\
0-\text { No appendicitis } \\
\text { Non-complicated appendicitis } \\
1 \text { - Acute appendicitis } \\
2 \text { - Ulcero phlegmonous appendicitis } \\
\text { Complicated appendicitis } \\
3 \text { - Necrotizing, gangrenous appendicitis } \\
4 \text { - Abscess formation } \\
5 \text { - Perforated appendicitis }\end{array}$ & $\begin{array}{c}13(4) \\
38(13) \\
155(51) \\
28(9) \\
8(3) \\
58(19)\end{array}$ & $\begin{array}{c}5(8) \\
2(3) \\
27(41) \\
8(13) \\
1(2) \\
21(33)\end{array}$ & $\begin{array}{c}8(3) \\
36(15) \\
128(54) \\
20(9) \\
7(3) \\
37(16) \\
\end{array}$ & $P=\mathbf{0 . 0 0 2}$ \\
\hline $\begin{array}{l}\text { Length of antibiotic treatment } \\
\text { None } \\
24 \mathrm{~h} \\
24-72 \mathrm{~h} \\
72-96 \mathrm{~h} \\
>5 \mathrm{~d} \\
\text { Unknown }\end{array}$ & $\begin{array}{c}208(68) \\
4(1) \\
8(3) \\
17(5) \\
63(21) \\
6(2)\end{array}$ & $\begin{array}{c}31(48) \\
0 \\
5(8) \\
8(12) \\
16(24) \\
5(8)\end{array}$ & $\begin{array}{c}177(73) \\
4(2) \\
3(1) \\
9(4) \\
47(20) \\
1(0)\end{array}$ & $P=0.001$ \\
\hline $\begin{array}{l}\text { Hospital stay, days } \\
1 \\
2 \\
3 \\
>3 \\
\text { Unknown }\end{array}$ & $\begin{array}{c}186(61) \\
40(13) \\
17(6) \\
56(18) \\
7(2)\end{array}$ & $\begin{array}{c}24(37) \\
14(22) \\
7(11) \\
14(22) \\
6(8)\end{array}$ & $\begin{array}{c}162(68) \\
26(11) \\
10(4) \\
42(17) \\
1(0)\end{array}$ & $P<0.001$ \\
\hline
\end{tabular}

172 Table 2: Operative and postoperative characteristics 
medRxiv preprint doi: https://doi.org/10.1101/2021.01.23.21250358; this version posted January 25, 2021. The copyright holder for this preprint

(which was not certified by peer review) is the author/funder, who has granted medRxiv a license to display the preprint in perpetuity.

All rights reserved. No reuse allowed without permission.

$\mathrm{SD}=$ standard deviation; $\mathrm{h}=$ hours

A significantly higher proportion of complicated appendicitis was observed in group A, based on the

Gomes and histopathological classifications being $52 \%$ and $48 \%$ in group $A$, and $20 \%$ and $28 \%$ in

group B. The rates of non-complicated and complicated appendicitis over the last 4 years in both groups are illustrated in Fig 1.

Fig 1. Distribution of complicated and non-complicated appendicitis. Distribution of noncomplicated and complicated appendicitis based on the laparoscopic grading score. Normal-looking appendix is not included in the graphic.

Patients in the COVID-19 group had a significantly longer intervention time, 77 vs. 61 minutes (mean, $P=0.002)$, and a higher rate of transabdominal drainage, $28 \%$ vs. $12 \%,(P=0.002)$ in group $A$ vs. $B$, respectively. Post surgery, there was a longer need for antibiotics in group A compared with group B patients $(P=0.001)$. The percentages of patients who underwent antibiotic therapy for more than 3 duration of antibiotic treatment was not available for five patients in group A .

In addition, patients in group A experienced a significantly longer hospital stay when compared with

192 patients of group B: $63 \%$ and $32 \%$ of patients were hospitalized $\geq 2$ days in groups A and B, respectively $(P<0.001)$.

\section{Discussion}

The present study demonstrates a diminished rate of patients presenting at the ER with acute 
medRxiv preprint doi: https://doi.org/10.1101/2021.01.23.21250358; this version posted January 25, 2021. The copyright holder for this preprint (which was not certified by peer review) is the author/funder, who has granted medRxiv a license to display the preprint in perpetuity.

All rights reserved. No reuse allowed without permission.

198

199

200

201

202

203

204

205

206

207

208

209

210

prolonged hospital stay in patients presenting during the COVID-19 pandemic period when compared with previous years.

The incidence of acute appendicitis during the COVID-19 pandemic is comparable to the findings of other reported studies [5-7, 10-12]. The encouragement by authorities to stay at home whenever possible, along with fear of being contaminated by the virus, might explain the fact of fewer consultations at emergency departments. Additionally, some spontaneous resolution of the disease might further explain the reduced rate of patients with diagnosis of acute appendicitis during the COVID-19 period. Seasonal changes and a tendency to a decreasing incidence of acute appendicitis over the years have also also reported as possible factors responsible for this finding [11, 13]. However, because in the present study the same seasonal periods over consecutive years were compared, it is unlikely that seasonal changes affected the incidence of acute appendicitis. A trend of fewer patients with acute appendicitis during the 3 previous years has not been confirmed by our evaluation.

Pre-operative investigations of the studied patients demonstrated a significantly higher CRP value at presentation in affected patients during the COVID-19 period when compared with previous time periods. Our study also demonstrated that the majority of patients (61\%) admitted during the COVID19 period presented later than 48 hours after the beginning of symptoms, compared with only $26 \%$ in previous years. A lower consultation rate and a higher delay to first consultation has been reported to be directly related to a higher rate of complicated appendicitis in such patients [14]. Our study confirms this finding, with significantly more patients with complicated appendicitis during the COVID-19 period when compared with previous years. This is in accord with other published reports [6-8, 10, 15]. However, Tankel et al. [5] did not observe different rates of non-complicated and complicated appendicitis during the COVID-19 pandemic. They therefore concluded that some patients with beginning appendicitis might possibly be treated conservatively. 
medRxiv preprint doi: https://doi.org/10.1101/2021.01.23.21250358; this version posted January 25, 2021. The copyright holder for this preprint (which was not certified by peer review) is the author/funder, who has granted medRxiv a license to display the preprint in perpetuity.

All rights reserved. No reuse allowed without permission.

222 Our results show a longer mean intervention time during the COVID-19 lockdown that is easily 223 explained by the higher rate of complicated appendicitis. In addition, most of our patients admitted during the lockdown period had a significantly longer hospital stay when compared with patients of the pre-pandemic group. Furthermore, prolonged post-operative antibiotic treatment during the COVID-19 period was noted with respect to the previous years, and this is also explained by the higher rate of complicated appendicitis. Interestingly, these results do not confirm those of other studies [6,7], where operation time and the post-operative recovery period were not different during the COVID-19-period (first wave) when compared with previous years.

Our study has some limitations. First, the period from March 12 to June 6 was chosen according to the coronavirus lockdown period in Switzerland. Choosing an earlier end date of the study might have led to different results. Second, general practitioners might have treated some patients conservatively without referring them to an emergency department, resulting in a possible underestimation of the total number of patients with appendicitis during this period. However, in our area general practitioners usually send most patients with a suspicion of acute appendicitis to the emergency department in order that they undergo imaging studies to confirm the suspected diagnosis. Thus, we believe that the number of patients who did not present to one of the participating hospitals was rather low.

In conclusion, the COVID-19 pandemic induced a decrease in acute appendicitis cases in the EDs, with a significant increase in complicated appendicitis. This phenomenon is most likely explained by symptomatic patients' substantially delaying medical consultation. The observed increased number of patients with complicated appendicitis was associated with a longer intervention time, longer antibiotic treatment, and a longer hospital stay compared with pre-pandemic patients. Since there might be another lockdown due to COVID-19 or other pandemics in future, it would be helpful to inform patients and general practitioners broadly of the importance of avoiding time delay from onset of symptoms to consultation. 
medRxiv preprint doi: https://doi.org/10.1101/2021.01.23.21250358; this version posted January 25, 2021. The copyright holder for this preprint (which was not certified by peer review) is the author/funder, who has granted medRxiv a license to display the preprint in perpetuity.

All rights reserved. No reuse allowed without permission.

248 Acknowledgments: We thank the surgical staff of the Daler hospital for the scientific collaboration.

The authors declare that they have no competing interests.

\section{References}

https://www.who.int/news-room/detail/29-06-2020-covidtimeline.

$4 \quad$ Perez KS, Allen SR. Complicated appendicitis and considerations for interval appendectomy. understanding of pathe (10000):1278-87.

5 Tankel J, Keinan A, Blich O, Koussa M, Helou B, Shay S, et al. The Decreasing Incidence of Acute Appendicitis During COVID-19: A Retrospective Multi-centre Study. World Journal of Surgery, 2020 Aug;44 (8):2458-2463.

6 Turanli S, Kiziltan G, Did the COVID-19 Pandemic Cause a Delay in the Diagnosis of Acute Appendicitis? World J Surg, 2021 Jan;45(1):18-22.

7 Orthopoulos G, Santone E, Izzo F, Tirabassi M, Perez-Caraballo A, Corriveau N, et al. Increasing incidence of complicated appendicitis during COVID-19 pandemic. Am J Surg, 2020 Sep 28; S0002-9610(20)30595-X.

8 Gao Z, Li M, Zhou H, Liang Y, Zheng C, Li S, et al. Complicated appendicitis are common during the epidemic period of 2019 novel coronavirus (2019-nCoV). Asian J Surg,2020 Oct;43(10):1002-1005.

9 Gomes CA, Sartelli M, Di Saverio S, Ansaloni L, Catena F, Coccolini F et al. Acute appendicitis: proposal of a new comprehensive grading system based on clinical, imaging and laparoscopic findings. World J Emerg Surg, 2015 Dec 3; 10:60.

10 Fisher JC, Tomita S, Ginsburg H, Gordon A, Walker D, Kuenzler K. Increase in Pediatric Perforated Appendicitis in the New York City Metropolitan Region at the Epicenter of the COVID-19 Outbreak. Ann Surg, 2020 Sep 24.

11 Snapiri O, Rosenberg C, Krause I, Kravarusic D, Yulevich A, Ball U, et al. Delayed diagnosis of paediatric appendicitis during the COVID-19 pandemic. Acta Paediatr, 2020 Aug;109(8):16721676.

12 Collard M, Lakkis Z, Loriau J, Mege D, Sabbagh C, Lefevre JH, et al. Antibiotics alone as an alternative to appendectomy for uncomplicated acute appendicitis in adults: Changes in treatment modalities related to the COVID-19 health crisis. J Visc Surg, 2020 Jun;157 (3S1):S33-S42.

13 York TJ, Seasonal and climatic variation in the incidence of adult acute appendicitis: a seven year longitudinal analysis. BMC Emerg Med, 2020 Apr 7; 20(1):24. 
medRxiv preprint doi: https://doi.org/10.1101/2021.01.23.21250358; this version posted January 25, 2021. The copyright holder for this preprint (which was not certified by peer review) is the author/funder, who has granted medRxiv a license to display the preprint in perpetuity. All rights reserved. No reuse allowed without permission.

29014 Tsioplis C, Brockschmidt C, Sander S, Henne-Bruns D, Kornmann M. Factors influencing the course of acute appendicitis in adults and children. Langenbecks Arch Surg, 2013 Aug;398(6):857-67.

15 Finkelstein P, Picado O, Muddasani K, Wodnicki H, Mesko T, Unger S, et al. A Retrospective Analysis of the Trends in Acute Appendicitis During the COVID-19 Pandemic. J Laparoendosc

296 Adv Surg Tech, 2020 Nov 11.

297 




